\title{
Clinical profile \& visual outcome in ocular chemical injury
}

\author{
Dubey A. ${ }^{1}$, Kubrey S.S. ${ }^{2}$, Kavita Kumar ${ }^{3}$
}

${ }^{1}$ Dr. Aditi Dubey, Assistant Professor, ${ }^{2}$ Dr. Suraj S. Kubrey, Associate Professor, ${ }^{3}$ Dr. Kavita Kumar, Professor \& Head, all authors are affiliated with Department of Ophthalmology, Gandhi Medical College, Bhopal, India.

Corresponding Author: Dr. Suraj Singh Kubrey, Department of Ophthalmology, $4^{\text {th }}$ floor Kamla Nehru Hospital, Gandhi Medical College, Bhopal (M.P.).Email: dr_kubrey@rediffmail.com

\begin{abstract}
Objective: To study the clinical profile \& visual outcome of ocular chemical injuries. Material \& Method: The cases of ocular chemical injury were included in the study. Detailed history of the patients was taken pertaining to the injury. The ocular examination was performed visual acuity was recorded by using Snellen's test type Chart. A thorough examination was carried out on slit-lamp, direct \& indirect ophthalmoscope. Clinical grading was done by Roper Hall Classification. Other ocular investigations were done when required. Results: The present study included 64 eyes of 54 patients, of which $80 \%$ (43) were male and $20 \%$ (11) females. The mean age was $22 \pm 13$ yrs. higher prevalence $66 \%$ of chemical ocular injury was seen in lower socioeconomic group. Alkali injuries $(66 \%)$ were more common than acid injuries (34\%). Calcium carbonate (lime) $31 \%$ was the most common etiological agent. Most chemical injuries were unilateral $81 \%$ Maximum no. of patients belongs to grade I (48\%) and minimum in grade IV (8\%). In grade I chemical injury, most patients were presented with visual acuity better than $6 / 12$. The final visual acuity is dependent on the initial grading and vision, higher the grade lesser are the chances of significant visual improvement. Conclusion: Presenting visual acuity is an important prognostic factor. Lower grades of injury had better final visual outcome. Grade III and grade IV alkali injuries are more severe injuries than acids.
\end{abstract}

Keywords: Chemical injury, Alkali injury, Acid injury

\section{Introduction}

Ocular chemical injuriesrepresent one of the true ocular emergencies. Chemical injury to the eye accounts for a significant portion of ocular trauma. Ocular Chemical injuries constitute $7.7 \%$ to $18 \%$ of all ocular traumas [1-4]. Chemical exposure to eye results in trauma ranging from mild irritation to severe damage to the ocular surface and anterior segment which can ultimately lead to permanent vision loss.

Chemical injury can be both from acid and alkali. Alkali injuries occur more frequent and severe than acid injuries $[1,5]$. Common causes of alkali injury included ammonia (NH3), lye $(\mathrm{NaOH})$, potassium hydroxide $(\mathrm{KOH})$, magnesium hydroxide $\left(\mathrm{MgOH}_{2}\right)$, and lime $\left(\mathrm{CaOH}_{2}\right)$ [6]. Lime is the most common cause of alkali injury. Ammonia, which is found in household cleaning agents and lye, is associated with the most severe alkali injuries. Alkalis penetrate more readily into the eye than acids, damaging stroma and endothelium as well as

Manuscript received: $4^{\text {th }}$ June 2019

Reviewed: $14^{\text {th }}$ June 2019

Author Corrected: $20^{\text {th }}$ June 2019

Accepted for Publication: $26^{\text {th }}$ June 2019 intraocular structures such as the iris, lens, and ciliary body. Irreversible intraocular damage has been noted to occur at aqueous $\mathrm{pH}$ levels of 11.5 or greater [7]. Ammonia can be detected in the anterior chamber with a rise in $\mathrm{pH}$ within seconds of exposure [8]. Sulfuric $\left(\mathrm{H}_{2} \mathrm{SO}_{4}\right)$, sulfurous $\left(\mathrm{H}_{2} \mathrm{SO}_{3}\right)$, hydrofluoric $(\mathrm{HF})$, acetic $\left(\mathrm{CH}_{3} \mathrm{COOH}\right)$, and hydrochloric (HCL) acids are the most common causes of acidic injuries [6].

Hydrofluoric acid causes the most serious acid injuries due to its low molecular weight, which allows easier penetration through the stroma [9]. The most common cause of acid injuries is sulfuric acid, which is commonly found in industrial cleaners and automobile batteries [9].

The injury may be compounded by thermal burns from heat generated by the acid's reaction with water of the precorneal tear film [10]. Acids generally cause less severe ocular injury than alkalis as the immediate precipitation of epithelial proteins offers some protection by acting as a barrier to intraocular penetration causing more superficial damage [11].

In addition to corneal and intraocular injury, chemical injuries result in complications due to damage to the 


\section{Original Research Article}

conjunctiva and anterior orbital tissues [12]. Ischemic necrosis of the conjunctiva induces the loss of vascularization at the limbus as well as the infiltration of leukocytes [13]. Late sequelae of severe injuries include cicatrization of the conjunctiva with symblepharon formation and entropion [13]. The sequels of chemical injury may have significant detrimental visual and psychological effects on the affected individual. Proper management in the acute setting as well as follow up is crucial in limiting adverse effects of ocular tissue damage secondary to the chemical injury.

\section{Material and Methods}

Setting: Department of Ophthalmology at a tertiary care hospital in central India

Duration: 1 year (Jan 2018-Dec 2018)

Type of study: Prospective observational study

Inclusion criteria: All cases of ocular chemical injuries who attended the ophthalmic casualty.

Exclusion criteria: Preexisting ocular pathology or other form of trauma.

Data collection procedure: Data was collected in Performa and spread in Microsoft excel sheet for analysis.

Data analysis: Data was analyzed with appropriate statistical variables like mean, standard deviation, chi square test, $p$ value using SPSS software.

Ethical consideration \& permission: Approval from the local Ethics Committee was obtained. The study adhered to the tenets of declaration of Helsinki.

Scoring system: Roper Hall Classification for grading of limbal ischemia in chemical burn was used.

\begin{tabular}{|c|l|c|}
\hline Grade 1 & Clear cornea (epithelial damage only) and no limbal ischaemia & Excellent prognosis \\
\hline Grade 2 & $\begin{array}{l}\text { Hazy cornea but with visible iris detail and less than one-third of the } \\
\text { limbus being ischaemic }\end{array}$ & Good prognosis \\
\hline Grade 3 & $\begin{array}{l}\text { Total loss of corneal epithelium, stromal haze obscuring iris detail and } \\
\text { between one-third and half limbal ischaemia }\end{array}$ & Guarded prognosis \\
\hline Grade 4 & An opaque cornea and more than 50\% of the limbus showing ischaemia & Poor prognosis \\
\hline
\end{tabular}

As soon as a case of ocular chemical injury presented to the casualty first aid was given in form ofthorough irrigation with ringer lactate or normal saline for minimum 30 minutes, $\mathrm{pH}$ was measured and superior and inferior fornix was examined for presence of any retained or embedded particulate matter and was removed carefully.

Detailed history of the patients and history of presenting complains was taken. The ocular examination was performed visual acuity was recorded by using Snellen's test type Chart. A thorough examination was carried out on slit-lamp, direct \& indirect ophthalmoscope. Clinical grading was done by Roper Hall Classification. Other ocular investigations were done when required. Patient was managed medically and/or surgically accordingly. Final visual outcome was noted at 3 months after injury.

\section{Results}

In the present study, 64 eyes of 54 patients were included of which $80 \%$ (43) were male and 20\% (11) females. The mean age was $22 \pm 13$ years. Most of the cases were students $41 \%$, followed by laborers $24 \%$.

As per the Kuppuswamy classification, maximum no. of cases were found in upper lower class $31 \%$, followed by $28 \%$ in lower middle class and $30 \%$ in upper middle class.

In the present study, Table 1 shows the distribution of chemical injuries alkali injuries were more common $66 \%$ ( 42 eyes) than acid injuries $34 \%$ (22 eyes).

Table-1: Table showing types of chemical agent causing chemical injury in eye ( $n=64$ eyes). 
Original Research Article

\begin{tabular}{|c|l|c|l|c|}
\hline $\begin{array}{c}\text { S. } \\
\text { No. }\end{array}$ & Acid Injury & $\begin{array}{c}\text { No of } \\
\text { Eyes }\end{array}$ & Alkali Injury & $\begin{array}{c}\text { No. of } \\
\text { Eyes }\end{array}$ \\
\hline 1 & $\begin{array}{l}\text { Sulphuric Acid } \\
\text { (Vitriolage, Mobile Battery) }\end{array}$ & 12 & Calcium Carbonate (Lime) & 20 \\
\hline 2 & $\begin{array}{l}\text { Sulphurous Acid } \\
\text { (Insecticide, Pesticide, Fruit Storage) }\end{array}$ & 2 & Magnesium Hydroxide (Firecracker) & 7 \\
\hline 3 & $\begin{array}{l}\text { Hydrochloric Acid } \\
\text { (Harpic Cleaning Agent) }\end{array}$ & 2 & $\begin{array}{l}\text { Ammonia (Cleaning Agents, Lysol, } \\
\text { Fertilizers) }\end{array}$ & 8 \\
\hline 4 & Hydroflouric Acid & 1 & Sodium Carbonate (Detergent) & 1 \\
\hline 5 & Cyanoacrylate (Fevikwik Superglue) & 1 & Calcium Silicate (Cement, Plaster) & 2 \\
\hline 6 & Unknown & 4 & Others (Holi Colour) & 4 \\
\hline & Total & $\mathbf{2 2}$ & Total & $\mathbf{4 2}$ \\
\hline
\end{tabular}

Most common causative agent of chemical injury was calcium carbonate (lime) 31\% (20 eyes) followed by ammonia $12 \%$ ( 8 eyes). Sulphuric acid (vitriolage, mobile battery) was the most common cause of acidic ocular injury $19 \%$ (12 eyes). Most of the cases had unilateral involvement 82\% (44 cases) and only 18\% (10 cases) in which alkali injury 34 $(72 \%)$ were more than acid injury $10(28 \%)$.

Table-2: Table showing incidence of laterality in chemical injury of eye ( $n=54$ cases).

\begin{tabular}{|c|c|c|c|c|c|}
\hline \multirow{2}{*}{ Laterality } & \multicolumn{2}{|c|}{ Acid Injury } & \multicolumn{2}{c|}{ Alkali Injury } & \multirow{2}{*}{ Total (\%) } \\
\cline { 2 - 5 } & $\begin{array}{c}\text { No. of } \\
\text { Patients }\end{array}$ & Percentage & $\begin{array}{c}\text { No. of } \\
\text { Patients }\end{array}$ & Percentage & \\
\hline Unilateral & 10 & 18 & 34 & 63 & $44(82 \%)$ \\
\hline Bilateral & 6 & 11 & 4 & 7 & $10(18 \%)$ \\
\hline Total & $\mathbf{1 6}$ & $\mathbf{3 0}$ & $\mathbf{3 8}$ & $\mathbf{7 0}$ & $\mathbf{5 4}$ \\
\hline
\end{tabular}

Maximum no. of bilateral cases was seen with acid injuries (Table 2).

Table-3: Grade-wise distribution of cases of chemical injury ( $n=64$ Eyes).

\begin{tabular}{|c|c|c|c|c|c|}
\hline \multirow{2}{*}{$\begin{array}{c}\text { Grade of } \\
\text { injury }\end{array}$} & \multicolumn{2}{|c|}{ Acid Injury } & \multicolumn{2}{c|}{ Alkali Injury } & \multirow{2}{*}{ Total (\%) } \\
\cline { 2 - 6 } & No. of eye & Percentage & No. of Eye & Percentage & \\
\hline I & 9 & 14 & 21 & 33 & $30(47 \%)$ \\
\hline II & 6 & 9 & 7 & 11 & $17(27 \%)$ \\
\hline III & 5 & 8 & 3 & 5 & $12(19 \%)$ \\
\hline IV & 2 & 3 & $\mathbf{4 2}$ & $\mathbf{6 6}$ & $5(8 \%)$ \\
\hline Total & $\mathbf{2 2}$ & $\mathbf{3 4}$ & $\mathbf{6 4}$ \\
\hline
\end{tabular}

As per the Roper Hall Classification, most of eyes sustained grade I chemical injury 47\% (30 eyes); followed by grade II with $27 \%$ : grade IV were $8 \%$ (Table 3). Most of the injured eye i.e. $78 \%$ had been exposed to chemical agent for a smaller duration of $<15$ min, only $6 \%$ with exposure of long duration of $>1$ hour.

It has been observed that the duration of exposure to chemical agent in most of the cases of less severe grade I and grade II injury i.e. $37 \%$ and $25 \%$ was $<15$ min while more severe grade III and grade IV injury had duration of exposure of $>15$. 
Table-4: Comparative analysis between different grades of chemical (acid /alkaline) injury and visual impact at presentation $(n=64$ eyes $)$.

\begin{tabular}{|c|c|c|c|c|c|c|c|c|c|}
\hline \multirow{2}{*}{$\begin{array}{c}\text { BCVA at } \\
\text { presentation }\end{array}$} & \multicolumn{7}{|c|}{ Acid Injury } & \multicolumn{5}{c|}{ Alkali Injury } & Total \\
\cline { 2 - 11 } & I & II & III & IV & I & II & III & IV & \\
\hline$\leq 6 / 12$ & 7 & 1 & - & - & 12 & 5 & - & - & 25 \\
\hline $6 / 18-6 / 60$ & 2 & 4 & - & - & 9 & 4 & 2 & - & 21 \\
\hline $5 / 60-1 / 60$ & - & 1 & 3 & - & - & 2 & 4 & - & 10 \\
\hline CF3FT-PL+ & - & - & 2 & 2 & - & - & 1 & 3 & 8 \\
\hline Total & $\mathbf{9}$ & $\mathbf{6}$ & $\mathbf{5}$ & $\mathbf{2}$ & $\mathbf{2 1}$ & $\mathbf{1 1}$ & $\mathbf{7}$ & $\mathbf{3}$ & $\mathbf{6 4}$ \\
\hline
\end{tabular}

Table 4 shows the visual acuity at presentation in comparison with the grading of acid/alkali injury. The chi-square statistic is 18.0795 ; the $\mathrm{p}$-value is 0.034263 . The result is significant at $\mathrm{p}<0.05$ i.e. the higher grade of ocular injury was associated with lower visual acuity.

Table-5: Correlation between grade of injury and final visual outcome (BCVA) at final follow up (n=64 eyes).

\begin{tabular}{|c|c|c|c|c|c|c|c|c|c|}
\hline \multirow{4}{*}{$\begin{array}{c}\text { Final } \\
\text { BCVA }\end{array}$} & \multicolumn{8}{|c|}{ Chemical Injury } & \multirow{4}{*}{ Total } \\
\hline & \multirow{2}{*}{\multicolumn{4}{|c|}{$\begin{array}{c}\text { Acid Injury } \\
\text { Grades }\end{array}$}} & \multicolumn{4}{|c|}{ Alkali Injury } & \\
\hline & & & & & \multicolumn{4}{|c|}{ Grades } & \\
\hline & I & II & III & IV & I & II & III & IV & \\
\hline$\leq 6 / 12$ & 9 & 5 & - & - & 18 & 7 & 1 & - & 40 \\
\hline $6 / 18-6 / 60$ & - & 1 & - & - & - & 2 & 1 & 1 & 5 \\
\hline $5 / 60-1 / 60$ & - & - & 2 & - & - & - & 4 & - & 6 \\
\hline CF3ft-PL+ & - & - & 3 & 2 & - & 1 & 1 & 2 & 9 \\
\hline Lost followup & - & - & - & - & 3 & 1 & - & - & 4 \\
\hline Total & 9 & 6 & 5 & 2 & 21 & 11 & 7 & 3 & 64 \\
\hline
\end{tabular}

Table 5 depicted the visual acuity at final follow-up. The chi-square statistic is 11.498 ; the p-value is 0.121503 . The result is insignificant; this shows that the final visual acuity is dependent on the initial grading and vision, higher the grade lesser are the chances of significant visual improvement. The complications that were noted in the present study were various grades of corneal opacities in $23 \%$ eyes, symblepharon in $8 \%$; ectropion $5 \%$.

\section{Discussion}

In the present study, the mean age of presentation was $22.09 \pm 13$ years emphasizing the vulnerability of young adults and school aged children. Kuckelhorn R et al [14] in a retrospective study on the incidence and prevalence of ocular chemical injury also reported that $70 \%$ of patients were adult males, $23 \%$ were adult females and $7 \%$ were children. Singh $\mathrm{P}$ et al [15] found that chemical injuries of the eyes occur most often among the age group from 20 to 40 years. Haring RS et al [16] reported median age of 22 years in their study done in the United State in sample of 900 patients. Adult males were most commonly affected as they are more exposed to chemical in working place. Second most common group is school aged children which were accidently exposed to chemicals during playing. In the previous studies of chemical injury of eye incidence in males had been high as compared to females.

As reported by other authors as well as in this study, male outnumbered females in the frequency of chemical injury with a ratio of 3.90:1 [14-18]. In the present study accidental and work related injuries were more common. Kuckelkorn $\mathrm{R}$ et al [14] in their study concluded that $73.8 \%$ were industrial accidents, while Midelfart A et al [19] stated that $49 \%$ chemical injury occurred in the workplace and $28 \%$ at home due to accidental exposure. Chemical ocular injuries are more common in lower social strata [16]. Prevalence of chemical injuries decreased with betterment in socioeconomic 
status and was more in lower classes. Studies have also reported a higher prevalence of chemical trauma among the illiterates, with illiteracy being more frequent in the lower socioeconomic group. Moreover poor knowledge about ocular safety and involvement in practices having higher risk of ocular injuries make them more prone of sustaining chemical injuries. Alkali injuries (66\%) were more common than acid injuries (34\%). Various previous studies have showed the similar results $[16,20]$.

Most common causative agent of chemical injury were sulphuric acid (19\%) among the acids and ammonia 8(12\%) out of 22 injured eyes and calcium carbonate (lime) 20(31\%) among the alkalis out of 42 injured eyes. According to Midelfart et al [19] and Vajpayee RB et al [18] and other authors have reported lime as the most common cause of alkali injuries.

Most of the cases presented with unilateral (82\%) involvement. Bilateral involvement was less common (18\%). The prevalence of alkali injury was more in alkali injury (72\%) were as bilateral involvement was more inacid injury (28\%). It was found that severe injuries i.e. grade III \& IV injuries were caused by alkalis being as alkali causes more tissue damage than acids due to its deeper penetration into the ocular tissue. Most of cases in the present study had lower grade of ocular injury as they were given prompt first aid on reaching to the hospital which decreases the ongoing process of ocular damage by removing the insulting chemical agent and $\mathrm{Ph}$ neutralization.

Conclusion: Early presentation with good presenting visual acuity carries a good structural and visual prognosis and lesser complications. Recovery rate in lower grades were higher than the more severe grades. Despite advances in medical and surgical treatment modalities, the consequences of severe ocular chemical burns can have profound psychological, economic, and social consequences for the patient. For this reason, a proactive approach to prevention becomes the effective. For this reason, a proactive approach to prevention becomes the effective. The principles of primary prevention include knowledge of risks via patient education and utilizing proper safety equipment (eyewear) and practices, are the best measures to avoid the arduous therapeutic course for recovery of vision. For patients presenting with chemical ocular injuries, whether they occur in the workplace or at home, early recognition and prompt treatment by the treating physician remain the standards for maximal preservation of ocular tissue and provide hope for preservation of vision.

\section{What this Study adds to existing knowledge?}

The findings of this study validate the present knowledge about ocular chemical burn. Also as per this study prompt first aid even before clinical assessment if initiated helps to reduce the grade and increase the prognosis of cases.

\section{Contribution of Authors.}

\begin{tabular}{|l|c|c|c|}
\hline & Aditi Dubey & Dr. Suraj S. kubrey & Dr. Kavita Kumar \\
\hline Conceived and designed the study & + & + & + \\
\hline Data collection & + & + & - \\
\hline Analysis of data & + & + & - \\
\hline Manuscript preparation & + & + & + \\
\hline
\end{tabular}

Funding: Nil, Conflict of interest: Nil

Permission from IRB: Yes

\section{References}

1. Pfister RR. Chemical injuries of the eye. Ophthalmology. 1983 Oct;90(10):1246-53.

2. Liggett PE, Pince KJ, Barlow W, et al. Ocular trauma in an urban population. Review of 1132 cases. Ophthalmology. 1990 May; 97(5):581-4.
3. Macewen CJ. Eye injuries: a prospective survey of 5671 cases. Br J Ophthalmol. 1989 Nov;73(11):888-94. DOI:10.1136/bjo.73.11.888

4. Zagelbaum BM, Tostanoski JR, Kerner DJ, et al. Urban eye trauma. A one-year prospective study. Ophthalmology. 1993 Jun;100(6):851-6. 


\section{Original Research Article}

5. Morgan SJ. Chemical burns of the eye: causes and management. Br J Ophthalmol. 1987 Nov;71(11):854-7. DOI:10.1136/bjo.71.11.854

6. Pfister R.R., Pfister D.R. Alkali injuries of the eye. In: Krachmer J.H., Mannis M.J., Holland E.J., ed. Cornea, Philadelphia: Elsevier Mosby; 2005: $1285-9.3$

7. Pfister RR, Friend J, Dohlman CH. The anterior segments of rabbits after alkali burns. Metabolic and histologic alterations. Arch Ophthalmol. 1971 Aug;86 (2): 189-93. DOI:10.1001/archopht.1971.0100001019 1013

8. Paterson C.A., Pfister R.R., Levinson R.A. Aqueous humor $\mathrm{pH}$ changes after experimental alkali burns. Am J Ophthalmol 1975; 79:414-9.

9. McCulley JP. Ocular hydrofluoric acid burns: animal model, mechanism of injury and therapy. Trans Am Ophthalmol Soc. 1990;88:649-84.

10. McCulley J.P. Chemical injuries. In: Smolin G., Thoft R.A., Ed. The cornea: scientific foundation and clinical practise, Boston: Little, Brown and Co; 1987: $527-42$.

11. Friedenwald J.S., Hughes W.F., Herrmann H.: Acid injuries of the eye. Arch Ophtalmol Rev Gen Ophtalmol 1946; 35:98-108.

12. Schirner G., Schrage N.F., Salla S., et al: Conjunctival tissue examination in severe eye burns: a study with scanning electron microscopy and energydispersive X-ray analysis. Graefes Arch Clin Exp Ophthalmol 1995; 233:251-6.
13. Wagoner MD. Chemical injuries of the eye: current concepts in pathophysiology and therapy. Surv Ophthalmol. 1997 Jan-Feb;41(4):275-313.

14. Kuckelkorn R, Luft I, Kottek AA, et al. Chemical and thermal eye burns in the residential area of RWTH Aachen. Analysis of accidents in 1 year using a new automated documentation of findings. KlinMonbl Augenheilkd. 1993 Jul;203(1):34-42. DOI:10.1055/s2008-1045646

15. Parul Singh, Manoj Tyagi, Yogesh Kumar, K. K. Gupta, P. D. Sharma. Ocular chemical injuries and their management;Oman J Ophthalmol. 2013;6(2):83-6

16. Haring RS, Sheffield ID, Channa R, et al. Epidemiologic Trends of Chemical Ocular Burns in the United States. JAMA Ophthalmol. 2016 Oct 1;134 (10): 1119-1124. doi: 10.1001/jamaophthalmol. 2016. 2645.

17. Adepoju FG, Adeboye A, Adigun IA. Chemical eye injuries: presentation and management difficulties. Ann Afr Med. 2007 Mar; 6(1):7-11.

18. Vajpayee RB, Shekhar H, Sharma N, et al. Demographic and clinical profile of ocular chemical injuries in the pediatric age group. Ophthalmology. 2014 Jan;121(1):377-380. doi: 10.1016/j.ophtha. 2013. 06. 044. Epub 2013 Aug 12.

19. Midelfart A, Hagen YC, Myhre GB. [Chemical burns to the eye]. Tidsskr Nor Laegeforen. 2004 Jan 8; 124 (1): 49-51.

20. Sher LM, Taylor DM, Robinson J, Browning J, Colbridge M, Macleod D, McCracken H, McKenzie C. Surveillance of severe chemical corneal injuries in the UK. Br J Ophthalmol. 2009 ;93(9):40-3.

\section{How to cite this article?}

Dubey A, Kubrey S.S, Kavita Kumar. Clinical profile \& visual outcome in ocular chemical injury. Trop J Ophthalmol Otolaryngol.2019;4(2):137-142.doi:10.17511/jooo.2019.102.12 